\title{
CONCENTRATION OF LIDOCAINE HYDROCHLORIDE \\ IN NEWBORN GASTRIC FLUID AFTER ELECTIVE \\ CAESAREAN SECTION AND VAGINAL DELIVERY \\ WITH EPIDURAL ANALGESIA
}

Sanjay Datta, Germain L. Houle, and Gordon S. Fox

SINCLAIR ${ }^{1}$ described gastric lavage for the treatment of foetal intoxication by a local anaesthetic after administration of caudal anaesthesia to four mothers in labour. The rationale of gastric lavage is based on the secretion of parenterally administered drugs into gastric juice. ${ }^{2}$

Lidocaine concentrations and $\mathrm{pH}$ of newborns' gastric fluid after vaginal delivery and elective caesarean section were measured to ascertain lidocaine concentrations and to correlate gastric $\mathrm{pH}$ and gastric concentration of the local anaesthetic. At the same time concentrations of lidocaine in maternal and umbilical blood were measured for comparison with gastric concentration.

\section{METHOD}

Forty parturients and neonates were studied after vaginal delivery. Lidocaine concentrations at delivery were determined in 29 maternal venous, 28 umbilical venous, 17 umbilical arterial and 29 foetal gastric fluid samples (Table I). Twentyfour parturients and neonates were studied during elective caesarean section. Lidocaine concentrations were measured in 19 maternal venous, 18 umbilical venous, 14 umbilical arterial and 19 foetal gastric fluid sample (Table I). The $\mathrm{pH}$ of the foetal gastric contents was determined in 21 samples after vaginal delivery and in 11 samples after Caesarean section (Table I).

Continuous lumbar epidural analgesia was provided for vaginal delivery with 1 per cent lidocaine containing 1:200,000 epinephrine. ${ }^{3}$ Lumbar epidural anaesthesia with 2 per cent lidocaine with 1:200,000 epinephrine was used for elective caesarean section. ${ }^{*}$

Five $\mathrm{ml}$ of heparinized maternal venous blood was collected before the epidural injection of lidocaine as a control for lidocaine assay. A section of umbilical cord, doubly clamped prior to placental separation, was obtained after delivery by both the vaginal and abdominal routes. Heparinized umbilical venous and arterial blood samples were collected. Another $5 \mathrm{ml}$ specimen of maternal heparinized blood was obtained at the time of delivery.

Gastric juice was aspirated from the infant's stomach through a catheter within three minutes after delivery. Maternal and neonatal blood samples and gastric juice were assayed for lidocaine concentration by gas chromatography. ${ }^{5}$ The $\mathrm{pH}$ of gastric juice was measured using an $\mathrm{IL} \mathrm{pH}$ electrode. The paired T-test was used to compare lidocaine concentrations in maternal and umbilical venous plasma

Department of Anaesthesia, Royal Victoria Hospital and McGill University.

Canad. Anaesth. Soc. J., vol. 22, no. 1, January 1975 
TABLE I

Number of Patients and Investigations

\begin{tabular}{lcc}
\hline \multicolumn{1}{c}{ Number } & $\begin{array}{c}\text { Elective } \\
\text { Caesarean Section }\end{array}$ & Vaginal Delivery \\
\hline $\begin{array}{l}\text { Total Cases } \\
\text { Maternal lidocaine } \\
\text { concentration (venous) }\end{array}$ & 24 & 40 \\
$\begin{array}{l}\text { Umbilical venous } \\
\text { lidocaine concentration }\end{array}$ & 19 & 29 \\
$\begin{array}{l}\text { Umbilical arterial } \\
\text { lidocaine concentration }\end{array}$ & 18 & 28 \\
$\begin{array}{l}\text { Foetal gastric } \\
\text { lidocaine concentration }\end{array}$ & 19 & 17 \\
Foetal gastric pH & 11 & 29 \\
\hline
\end{tabular}

and gastric juice. Comparison between the gastric content of lidocaine and umbilical arterial lidocaine concentration was not done because of an insufficient number of umbilical arterial samples. The unpaired T-test was used to compare foetal $\mathrm{pH}$ and gastric lidocaine concentrations between Caesarean sections and vaginal deliveries.

\section{Results}

Table II indicates the maternal body weight, dose of lidocaine, time from initial injection of lidocaine to delivery of the baby, maternal lidocaine concentrations, umbilical venous and umbilical arterial lidocaine concentrations, foetal gastric lidocaine concentration and foetal gastric $\mathrm{pH}$ in elective Caesarean sections and vaginal deliveries.

The mean gastric juice $\mathrm{pH}$ of $7.75(\mathrm{SD} \pm 0.29)$ after elective Caesarean section was significantly higher than the $\mathrm{pH}$ of $7.05( \pm 0.69)$ found after vaginal delivery.

TABLE II

Subject Data - Mean Results

\begin{tabular}{|c|c|c|}
\hline & $\begin{array}{c}\text { Elective } \\
\text { Caesarean Section }\end{array}$ & $\begin{array}{l}\text { Vaginal } \\
\text { Deliveries }\end{array}$ \\
\hline Maternal Weight (kg) & $71.0 \quad( \pm 10.0)$ & $68.0( \pm 9.0)$ \\
\hline Dose of lidocaine $(\mathrm{mg})$ & $( \pm 34)$ & $( \pm 88)$ \\
\hline $\mathrm{T}-\mathrm{D}(\min )$ & $20.4( \pm 3.6)$ & $( \pm 88)$ \\
\hline $\begin{array}{l}\text { Maternal lidocaine } \\
\text { concentration }(\mu \mathrm{g} / \mathrm{ml})\end{array}$ & $1.2( \pm 0.71)$ & $0.90( \pm 0.44)$ \\
\hline $\begin{array}{l}\text { Umbilical venous lidocaine } \\
\text { concentration }(\mu \mathrm{g} / \mathrm{ml})\end{array}$ & $0.72( \pm 0.59)$ & $0.53( \pm 0.24)$ \\
\hline $\begin{array}{l}\text { Umbilical arterial lidocaine } \\
\text { concentration }(\mu \mathrm{g} / \mathrm{ml})\end{array}$ & $0.55( \pm 0.39)$ & $0.40( \pm 0.2)$ \\
\hline $\begin{array}{l}\text { Foetal gastric lidocaine } \\
\text { concentration }(\mu \mathrm{g} / \mathrm{m})\end{array}$ & $0.82( \pm 0.99)^{*}$ & $2.11( \pm 1.6)^{*}$ \\
\hline Foetal gastric $\mathrm{pH}$ & $7.75( \pm 0.29)^{*}$ & $7.05( \pm 0.69)^{*}$ \\
\hline
\end{tabular}

()$= \pm$ standard deviation.

$\mathrm{T}-\mathrm{D}=$ Time from initial injection of lidocaine to delivery of baby.

${ }^{*} p<0.001$. 


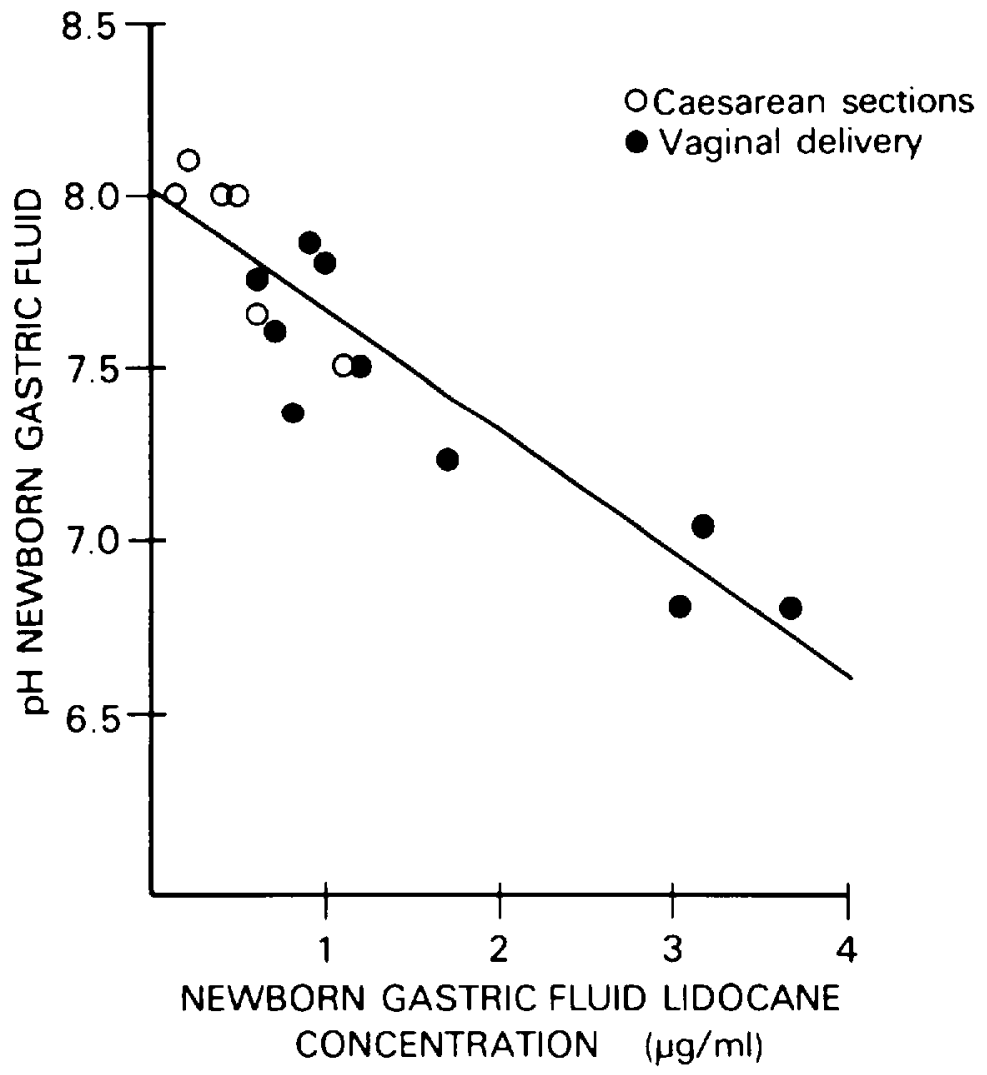

Figure 1. Correlation between gastric fluid $\mathrm{pH}$ and lidocaine concentration $(\mathrm{r}=0.92 ; \mathrm{p}<$ $0.001)$.

The range of the $\mathrm{pH}$ of the gastric secretions agrees with the data previously reported. ${ }^{6}$

Gastric lidocaine concentrations differed significantly between the two groups; $0.82 \mu \mathrm{gm} / \mathrm{ml}( \pm 0.99)$ after elective Caesarean section and $2.11 \mu \mathrm{gm} / \mathrm{ml}( \pm 1.6)$ after vaginal delivery. The correlation between gastric $\mathrm{pH}$ and lidocaine concentration is shown in Figure 1. Lower gastric lidocaine concentrations were found as the gastric fluid $\mathrm{pH}$ increased $(\mathrm{r}=0.92 \mathrm{p}<0.001)$.

The maternal, umbilical venous and arterial lidocaine concentrations correspond with previous studies. ${ }^{4,7}$

Gastric lidocaine concentrations were similar to those in maternal and umbilical venous blood after elective Caesarean section but were significantly higher than either maternal or umbilical venous lidocaine concentrations after vaginal delivery $(\mathrm{p}<0.001)$.

\section{Discussion}

Shore ${ }^{2}$ has shown that weak bases will cross the plasma/gastric barrier and become concentrated in acid gastric juice. Weak bases will ionize to a greater degree in an acid medium than in a basic or neutral environment. 
Lidocaine is a weak base with $\mathrm{pKa}$ of $7.80 .{ }^{4}$ Previous studies have shown lidocaine to be present in foetal blood after lumbar epidural analgesia. ${ }^{4,7}$ In order to cross the lipoid placental barrier the molecule must be in its undissociated form. ${ }^{8}$ The degree of dissociation of the lidocaine molecule in foetal blood is dependent on the $\mathrm{pH}$ of foetal plasma. Since foetal plasma $\mathrm{pH}$ is less than maternal, ${ }^{9}$ the degree of ionization of the molecule is relatively greater in foetal blood than in maternal. However, unionized lidocaine molecules are able to cross the foetal lipoid gastric barrier" and dissociate according to the gastrict $\mathrm{pH}$. Ionized molecules in the gastric fluid are trapped within the gastric compartment.

We found the gastric juice in the foetus more acidic after vaginal delivery than after elective Caesarean section. In accordance with the above theory, the foetal lidocaine concentration was higher in the former situation than in elective Caesarean section.

Brown ${ }^{10}$ reported that the concentration of mepivacaine in the stomach of the newborn exceeded that in cord blood after vaginal delivery. The concentrations in maternal and umbilical blood, and in gastric fluid are higher than in our series. Comparison between lidocaine and mepivacaine and consequently comparison of Brown's report and this one are acceptable because both local anaesthetics cross the placenta to a similar degree. ${ }^{11}$ Higher gastric concentrations are due partly to higher maternal and umbilical blood concentrations resulting from a higher mean total dose of local anaesthetic for maternal epidural analgesia. The time of gastric sampling may also be important because newborn gastric fluid becomes more acidic soon after delivery. ${ }^{6}$ Brown sampled gastric fluid for up to fifteen minutes after delivery in comparison to within three minutes in our series.

This study confirms the presence of lidocaine in neonatal stomachs at delivery after maternal lumbar epidural anaesthesia. The implications are that in case of neonatal intoxication with lidocaine, gastric washout of the newborn may be more cffective in reducing foetal blood concentrations after vaginal delivery than after elective Caesarean section.

\section{SUMmary}

Lidocaine concentrations were measured after vaginal delivery or Caesarean section with epidural anaesthesia in samples of maternal and umbilical blood and in newborn gastric contents. The $\mathrm{pH}$ of the gastric aspirate was also determined in a number of neonates. Gastric lidocaine concentrations were higher and the $\mathrm{pH}$ was lower after vaginal delivery in comparison to Caesarean section. A significant inverse correlation exists between gastric $\mathrm{pH}$ and gastric lidocaine concentration. Neonate gastric lidocaine concentration was significantly higher than in maternal or umbilical venous plasma after vaginal delivery, but not after Caesarean section. Due to these differences, gastric lavage for the treatment of neonatal lidocaine intoxication may be more beneficial in reducing foetal systemic local anaesthetic concentration after vaginal than after elective abdominal delivery.

\section{ACKNOWLEDGMENTS}

Appreciation is expressed to Mr. A. Edhorn, Chief Chemist, Astra Chemicals for determinations of lidocaine concentration, and to Dr. H. Himal, Department of Surgery, for $\mathrm{pH}$ determinations of gastric juice. 
RÉSUMÉ

Suivant un accouchement ou une césarienne sous anesthésie péridurale, la concentration de lidocaine a été estimée dans le sang de la mére et du cordon ombilicale ainsi que dans les secretions gastriques du nouveau-né. Le pH des sucs gastriques a aussi été évalué chez un certain nombre de nouveau-nés. La concentration gastrique de lidocaine a été plus elevée et le $\mathrm{pH}$ plus bas dans les accouchements que dans les césariennes. Une correlation inverse existe entre le $\mathrm{pH}$ des secretions gastriques et la concentration gastrique de lidocaine. La concentration gastrique de lidocaine etait plus elevée de façon significative dans les echantillons sangins de la mére et de la veine ombilicale après l'accouchement mais non suivant une césarienne. A cause de ces différences, le lavage gastrique au pour le traitement de l'intoxication au lidocaine du neuveau-né serait plus efficace à diminuer la concentration systemique de l'anesthesique local après un accouchement que suivant une césarienne.

\section{REFERENCES}

l. Sinclaik, J.C., Fox, H.A., Leutz, J.F., Fuld, G.L., \& Murphy, J. Intoxication of the fetus by a local anaesthetic. New Engl. J. Med. 273: 1173 (1965).

2. Shore, P.A., Brodie, B.B., \& Hocben, C.A.M. The gastric secretion of drugs: a pH partition hypothesis. J. Pharmacol, Exp. Ther.

3. BRomage, P.R. Continuous lumbar epidural analgesia for obstetrics. C.M.A.J. 85: 1135 (1961).

4. Fox, G.S. \& Houle, G.L. Transmission of lidocaine $\mathrm{HCl}$ across the placenta during Caesarean section. Canad. Anaesth. Soc. J. 16: 135 (1969).

5. Edhorn, G.A. Determination of lidocaine in whole blood by gas chromatography. Canad. Anaesth. Soc. J. 18: 189 (1971).

6. SMith, C.A. The physiology of the newborn infant. 2nd ed. p. 189. Springfield, Illinois. Charles C. Thomas (1953).

7. Fox, G.S., Houle, G.L., Desjardin, P.D., \& Mercier, G. Intrauterine fetal lidocaine concentrations during continuous epidural analgesia. Amer. J. Obstet. Gynec. 110: 896 (1971).

8. Moya, F. Considerations in maternal and placental physiology. Anesth. and Analg. 42 : 661 (1963).

9. Fox, G.S. \& Houle, G.L. Acid-base studies in elective Caesarean section during epidural anaesthesia. Canad. Anaesth. Soc. J. 18: 60 (1971).

10. Brown, W.U., Bell, G.C., \& Alper, M.H. Abstracts of scientific papers. p. 257 (1972). A.S.A. Annual Meeting.

11. Fox, G.S. \& Houle, G.L. Transmission of lidocaine hydrochloride across the placenta during Caesarean section. Canad. Anaesth. Soc. J. 16: 135 (1969). 